\title{
Antiviral activity of merimepodib against foot and mouth disease virus in vitro and in vivo
}

\author{
Shi-fang Li, Mei-jiao Gong, Jun-jun Shao, Yue-feng Sun, Yong-guang Zhang, Hui-yun Chang* \\ State Key Laboratory of Veterinary Etiological Biology, OIE/National Foot-and-Mouth Disease Reference Laboratory, Lanzhou Veterinary Research Institute, Chinese \\ Academy of Agricultural Sciences, Lanzhou, 730046, Gansu, China
}

\section{A R T I C L E I N F O}

\section{Keywords:}

FMDV

Merimepodib

Antiviral activity

In vivo

\begin{abstract}
A B S T R A C T
Foot and mouth disease virus (FMDV), a member of family Picornaviridae, belongs to the genus Aphthovirus, which causes foot and mouth disease (FMD), a highly transmissible disease that affects cloven-hoof animals. In spite of the fact that efficient vaccines are available, effective antiviral molecules for FMD are needed to reduce viral infection during early stages of infection. In this study, merimepodib was found to efficiently inhibit FMDV replication in a dose-dependent manner. The $50 \%$ inhibitory concentration $\left(\mathrm{IC}_{50}\right)$ of merimepodib antiviral activity against two distinct FMDV strains (O/MYA98/BY/2010 and A/GD/MM/CHA/2013) was estimated to be 7.859 and $2.876 \mu \mathrm{M}$, respectively, while the $50 \%$ cytotoxic concentration $\left(\mathrm{CC}_{50}\right)$ of merimepodib was found to be $47.74 \mu \mathrm{M}$. Furthermore, treatment with $30 \mu \mathrm{g}$ merimepodib efficiently prolonged the survival time of suckling mice infected with FMDV. Taken together, these results suggested that merimepodib has the potential to be a novel antiviral agent against FMDV.
\end{abstract}

\section{Introduction}

Foot-and-mouth disease (FMD) is one of the most highly contagious viral diseases of cloven-hoofed animals that has significant economic effects in affected countries (Moraes et al., 2007). Owing to the fact that of the rapid spread of the FMD virus (FMDV) in susceptible animals, FMD has been listed as a serious disease by the World Organization for Animal Health and in China. The virus, FMDV belongs to the genus Aphthovirus in the family Picornaviridae (Bachrach, 1968), and its genome is an $8.5-\mathrm{kb}$, positive-sense single-stranded RNA containing a 5 '-untranslated region (5'-UTR), one open reading frame, and a 3'-UTR. The FMDV includes seven serotypes: A, O, Asia1, C, Southern African Territories (SAT) 1, 2 and 3; in addition, many subtypes have evolved within each serotype and there is little to no cross immunity between the different serotypes (Domingo et al., 2003; Moraes et al., 2007; Knowles and Samuel, 2003). Until now, FMD has been successfully controlled by vaccination in many developing countries. However, current FMD vaccines have several unfavorable properties, such as narrow antigenic profiles, trade restrictions and delayed antibody responses (Diaz-San et al., 2011; Belsham et al., 2011). Importantly, the use of current FMD vaccines to induce early protection is limited; because protection is not effective until 7 days after vaccination (Golde et al., 2005). Therefore, an alternative method of applying antiviral agents is urged to decrease the spread of FMDV in outbreak situations.
Inosine-5'-monophosphate dehydrogenase (IMPDH) is an enzyme of the de novo purine nucleotide biosynthesis pathway (Hedstrom, 2009). Thus, inhibition IMPDH could decrease the intracellular guanine nucleotide levels that are required for RNA and DNA synthesis. Merimepodib, an IMPDH inhibitor, was originally developed for the treatment of hepatitis C virus (HCV). Merimepodib was reported to inhibit HCV in cultured cells with an $\mathrm{IC}_{50}$ of $0.39 \mu \mathrm{M}$ (Marcellin et al., 2007), while in HCV patients, merimepodib was shown to be well-tolerated when combined with PEGylated interferon alpha 2a and ribavirin for up to 48 weeks in phase 2a and 2b studies (Rustgi et al., 2009; Marcellin et al., 2007). Besides, it has been demonstrated to have activity against a variety of DNA viruses (hepatitis B virus, human cytomegalovirus and herpes simplex virus type 1) and RNA viruses (respiratory syncytial virus, parainfluenza 3 virus, bovine viral diarrhea virus, Venezuelan equine encephalomyelitis virus and encephalomyocarditis virus) in vitro (Markland et al., 2000). Recently, Tong and others (Tong et al., 2018) reported that merimepodib inhibited the replication of ZIKV and several important emerging viral pathogens (Ebola, Lassa, Chikungunya and Junin viruses) in cultured cells; yet the antiviral effect of merimepodib on FMDV infection remains unclear. In this report, we explored the potency of merimepodib against FMDV, and the results showed that merimepodib was able to effectively inhibit FDMV infection in vitro and in vivo; moreover, the antiviral effect can be attenuated by guanosine supplementation. Our findings suggest that merimepodib

\footnotetext{
*Corresponding author at: No.1 Xujiaping, Yanchangbao, Chengguan District, Lanzhou, 730046, Gansu, China.

E-mail address: changhuiyun@caas.cn (H.-y. Chang).
} 
A

B

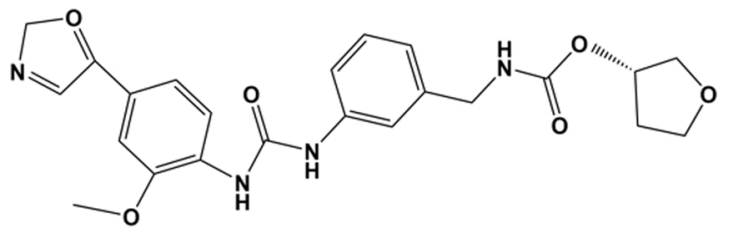

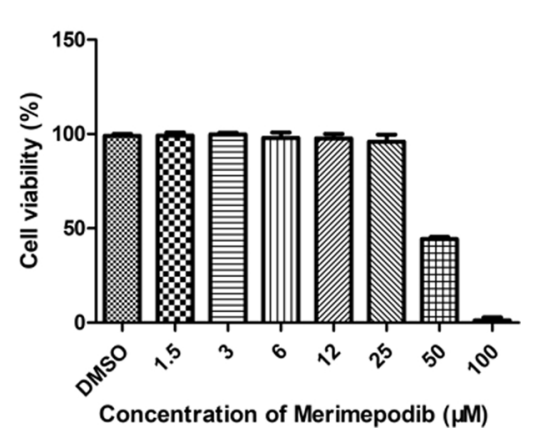

Fig. 1. Cytotoxicity effect of merimepodib in IBRS-2 cells. (A) Molecular structures of merimepodib. (B) Determination of $\mathrm{CC}_{50}$ of merimepodib. IBRS-2 cells were seeded in 96well plates and left to attach. The monolayers of cells were treated with or without merimepodib at specified concentrations. As a control, the cells were treated with $0.5 \%$ DMSO. Cell viability was determined after $72 \mathrm{~h}$ of post-treatment using MTS assay. may serve as a potential antiviral agent for FMDV infection.

\section{Materials and methods}

\subsection{Reagents and antibodies}

Merimepodib (Fig. 1A) and guanosine were purchased from MCE (MedChemExpress). BCA Kit, TRIZOL and Pierce ${ }^{\mathrm{TM}}$ ECL Western Blotting Substrate were acquired from Thermo Fisher Scientific. Type O FMDV VP1 rabbit polyclonal antibodies and rabbit hyper-immune serum raised against type O FMDV (O/MYA98/BY/2010) were provided by Hai-xue Zheng and Guang-qing Zhou (OIE/National Foot-and-Mouth Disease Reference Laboratory), respectively. Antibodies against $\beta$-actin were acquired from Sigma (USA). Peroxidase-Conjugated Goat antirabbit IgG $(\mathrm{H}+\mathrm{L})$, Horseradish peroxidase (HRP)-conjugated goat antimouse IgG or anti-rabbit IgG were acquired from ZSGB, (Beijing, China). PrimeScript ${ }^{\mathrm{TM}}$ RT reagent kit containing gDNA Eraser and SYBR Premix Ex Taq ${ }^{\mathrm{TM}}$ II (Tli RNaseH Plus) were acquired from TaKaRa. MTS assay were purchased from Abcam. SPlink Detection Kits was acquired from ZSGB (Beijing, China).

\subsection{Cell lines, virus and animals}

IBRS-2 cells (swine kindy cell lines) were cultured in Dulbecco's modified Eagle's medium (DMEM, Gibco, Grand Island, NY) supplemented with $10 \%$ fetal bovine serum (FBS), penicillin and streptomycin (10 units/ml, HyClone) at $37{ }^{\circ} \mathrm{C}$ in a humid atmosphere of $5 \% \mathrm{CO}_{2}$. FMDV O/MYA98/BY/2010 and A/GD/MM/CHA/2013 were preserved and provided by OIE/National Foot-and-Mouth Disease Reference Laboratory of China, and their 50\% tissue culture infective dose $\left(\mathrm{TCID}_{50}\right)$ were calculated using the Reed-Muench method. Suckling mice, aging 2-3 days, were obtained from Lanzhou Veterinary Research Institute and were maintained on a $12 \mathrm{~h}$ light and $12 \mathrm{~h}$ dark cycle with a temperature at $23{ }^{\circ} \mathrm{C}$ and a relative humidity between 50 and $55 \%$. Animal experiments were performed at Biosafety Level 3 laboratory of Lanzhou Veterinary Research Insititute, Chinese Academy of Agricultural Sciences and were approved by the Animal Ethics Committee of Lanzhou Veterinary Research Institute (No. LVRIAEC2018-007).

\subsection{Assessment of cytotoxicity of merimepodib on IBRS-2 cells}

Merimepodib was used diluted to a concentration ranging from $75 \mu \mathrm{M}$ to $1.5 \mu \mathrm{M}$ with DMEM containing $2 \%$ FBS and supplemented with penicillin and streptomycin. IBRS-2 cells monolayers in 96-well plates were exposed then to the respective merimepodib solutions. After $72 \mathrm{~h}$, the supernatant was removed, and $20 \mu \mathrm{L}$ MTS was added to each well and incubated for $4 \mathrm{~h}$. The absorbance value at $490 \mathrm{~nm}$ was measured using a microplate reader (Thermo Fisher Scientific, USA). All the experiments were carried out in triplicate.

\subsection{Assessment of antiviral activity of merimepodib}

Merimepodib at five different concentrations, from 1.5 to $25 \mu \mathrm{M}$, was subsequently used for determination of antiviral activity using the MTS method. Briefly, IBRS-2 cells were seeded into 96-well cell culture plates at $3 \times 10^{4}$ cells/well. On the next day, IBRS- 2 cells were challenged with 100 TCID $_{50}$ FMDV O/MY98/BY/2010 and A/GD/MM/ 2013, respectively. After $1 \mathrm{~h}$ of infection, cells were washed with DMEM thrice to remove free virus and were then subsequently treated with $0.5 \%$ DMSO (control) or drugs. The cells were incubated at $37^{\circ} \mathrm{C}$ for $48 \mathrm{~h}$ until the maximum cytopathic effect (CPE) of FMDV was reached. An MTS assay was then initiated and the absorbance (optical density [OD]) at $490 \mathrm{~nm}$ was recorded. CPE inhibition was calculated as: $\left[(\mathrm{ODtreated})_{\mathrm{FMDV}}-\mathrm{OD}_{\mathrm{VC}}\right] /\left[\mathrm{OD}_{\mathrm{CC}}-\mathrm{OD}_{\mathrm{VC}}\right]$; whereby (ODtreated) $)_{\mathrm{FMDV}}$ represented the OD of virus-infected cells treated with drugs, while $\mathrm{OD}_{\mathrm{CC}}$ is the absorbance obtained with uninfected untreated cells; $\mathrm{OD}_{\mathrm{VC}}$ represents the absorbance value of infected untreated cells. The $\mathrm{IC}_{50}$ was defined as the compound concentration required to reduce viral CPE by $50 \%$ of the virus control. The $\mathrm{IC}_{50}$ values of merimepodib were calculated as the mean \pm SD at least three independent experiments. The selectivity index (SI) was obtained by calculating the ratio of the $\mathrm{CC}_{50} / \mathrm{IC}_{50}$. Total RNA from each well was isolated, and the relative mRNA levels were assessed by Q-PCR analysis.

\subsection{Treatment with exogenous guanosine}

IBRS-2 cells were infected with 100 TCID $_{50}$ FMDV O/MY98/BY/ 2010 for $1 \mathrm{~h}$. After incubation, cells were washed and treated with either $0.5 \%$ DMSO, $100 \mu \mathrm{M}$ guanosine, $25 \mu \mathrm{M}$ merimepodib, or merimepodib supplemented with a serial dilution of guanosine (from $100 \mu \mathrm{M}$ to $25 \mu \mathrm{M}$ ) for $48 \mathrm{~h}$. After incubation, viral protein and gene expression was assessed by western blot and Q-PCR, respectively.

\subsection{Time course analysis}

To further investigate the correlation between merimepodib and virus replication, a time course analysis was conducted according to the methods described by Usharani and others (Usharani et al., 2017). IBRS-2 cells $\left(3 \times 10^{5}\right.$ cells/well) grown in 12-well plates were infected with $100 \mathrm{TCID}_{50}$ FMDV O/MY98/BY/2010 for $1 \mathrm{~h}$ at $37^{\circ} \mathrm{C}$ for viral absorption after which $25 \mu \mathrm{M}$ merimepodib was added to the cells at 0 , 2, 48 and $16 \mathrm{~h}$ postinfection (p.i.), respectively. Finally, the cells were collected at $48 \mathrm{~h}$ p.i. The inhibitory effects were determined using the Q-PCR and western blot.

\subsection{Indirect immunoinfluscent assay (IFA)}

IBRS-2 cells were seeded into 12-well cell culture plates at $3 \times 10^{5}$ cells/well and grown until $90 \%$ confluent, and then, the cells were challenged with 100 TCID $_{50}$ FMDV (O/MY98/BY/2010). $1 \mathrm{~h}$ later, the 
infection mixtures were removed and replaced with a medium containing a serial dilutions of merimepodib with an initial concentration of $25 \mu \mathrm{M}$ were cultured for $12 \mathrm{~h}$ at $37{ }^{\circ} \mathrm{C}$ and then fixed with $4 \%$ paraformaldehyde for $15 \mathrm{~min}$. After washing three times with PBS, the cells were incubated with rabbit hyper-immune serum (1:150) against FMDV for $1 \mathrm{~h}$. The cells were then washed three times with PBS and subsequently were incubated with peroxidase-conjugated goat anti-rabbit IgG $(\mathrm{H}+\mathrm{L})$ for $1 \mathrm{~h}$. Finally, the cells were observed with a fluorescence microscope after three washing with PBS. Lastly, positive cells were detected using a fluorescent microscope Nikon ECLIPSE TS100 fluorescence microscope (Nikon, Japan).

\subsection{Western blotting analysis}

The collected cells were lysed and protein concentration was determined using the BCA assay. Primary antibodies included an antiFMDV-VP1 polyclonal antibody $(1: 1,000)$ and anti- $\beta$-actin polyclonal antibody $(1: 4,000)$, followed by incubation with a horseradish peroxidase-conjugated goat anti-mouse IgG or anti-rabbit IgG. Finally, protein bands were visualized using Pierce ${ }^{\mathrm{TM}}$ ECL Western Blotting Substrate.

\subsection{RNA extraction and Q-PCR analysis}

Total RNAs were extracted from cultured cells using TRIzol reagents according to the manufacturer's instructions. cDNAs were synthesized using a PrimeScript ${ }^{\mathrm{TM}}$ RT reagent kit containing gDNA Eraser with random hexamers. The synthesized cDNAs were subjected to Q-PCR analysis using specific primers as described previously (Li et al., 2019). Q-PCR was performed in triplicate on an Agilent Technologies Stratagene Mx3005 P instrument (Agilent, USA) using SYBR Premix Ex Taq ${ }^{\mathrm{TM}}$ II (Tli RNaseH Plus) in a $25 \mu \mathrm{L}$ reaction mixture. Q-PCRs were run at $95^{\circ} \mathrm{C}$ for $30 \mathrm{~s}$ and 40 cycles at $95^{\circ} \mathrm{C}$ for $5 \mathrm{~s}, 56^{\circ} \mathrm{C}$ for $30 \mathrm{~s}$, and $72{ }^{\circ} \mathrm{C}$ for $30 \mathrm{~s}$, followed by melting curve analysis. The RNA level was normalized to porcine $\beta$-actin and the relative quantities of mRNA were evaluated using the $2^{-\Delta \Delta \mathrm{Ct}}$ threshold cycle method.

\subsection{Animals experiments}

To test the antiviral activity of merimepodib in vivo, 3-day-old $\mathrm{BALB} / \mathrm{c}$ suckling mice were used. The $50 \%$ lethal dose $\left(\mathrm{LD}_{50}\right)$ of FMDV O/MYA98/BY/2010 was determined by the Reed and Muench method. The mice were divided into two groups (12 mice per group). One group received $100 \mu \mathrm{L}$ of PBS containing 10\% DMSO and 5\% Tween-80 (control group); the other group received $30 \mu \mathrm{g}$ of merimepodib dissolved in 10\% DMSO and 5\% Tween-80 in $100 \mu \mathrm{L}$ PBS. Two hours later, each mouse was injected subcutaneously into the cervical dorsal area with $100 \mu \mathrm{L}$ of diluted virus at $100 \mathrm{LD}_{50}$ FMDV O/MYA98/BY/2010. The percentage of surviving suckling mice was recorded every $12 \mathrm{~h}$ until 5 days after inoculation.

\subsection{Histology and immunohistochemistry}

Heart tissue was removed from euthanized mice and fixed in $4 \%$ formalin at room temperature for $48 \mathrm{~h}$. Serial tissue sections $5 \mu \mathrm{m}$ thick were obtained after embedding in paraffin. Each section was stained with hematoxylin and eosin (H\&E) and then examined under a microscope (BA400Digital, Motic). Ten sections of heart tissue were observed per animal in a blinded manner. Examination of FMDV antigen in tissue samples was performed using immunohistochemistry. Sections were incubated in $10 \%$ normal goat serum in PBS for 20 min to block nonspecific binding sites before reacting with the rabbit hyper-immune serum raised against type O FMDV (O/MYA98/BY/2010) in PBS overnight at $4{ }^{\circ} \mathrm{C}$. Slides were further incubated with SPlink Detection Kits for $30 \mathrm{~min}$. Staining was visualized by the addition DAB for $2 \mathrm{~min}$ and counterstained with $\mathrm{H} \& \mathrm{E}$, mounted with neutral gum and then examined using a digital microscope (BA400Digital, Motic, China). Optical density (OD) was measured using Image-Pro Plus 6.0 software to evaluate of FMDV antigen per section from each block.

\subsection{Statistical analysis}

Differences between treated and control groups were analyzed by a one-way analysis of variance and least significant difference post hoc test. Results are expressed as the means \pm S.D of the mean from three independent observations. Statistical analysis was performed using SPSS version 16.0 software. $P<0.05$ was considered as statistically significant difference.

\section{Results}

\subsection{Cytotoxicity}

To rule out the possibility that the antiviral activity was due to cytotoxicity of the merimepodib, an MTS cell viability assay was performed. The relative cell viability was above $90 \%$ after treatment with merimepodib at concentrations of $1.5,3,6,12$, and $25 \mu \mathrm{M}$; however, the viability was under $50 \%$ after treatment with merimepodib at concentrations of 50 and $100 \mu \mathrm{M}$ (Fig. 1B), with the $50 \%$ cytotoxic concentration $\left(\mathrm{CC}_{50}\right.$ ) of merimepodib found to be $47.74 \mu \mathrm{M}$. At a concentration of $25 \mu \mathrm{M}$ merimepodib, which was below the $\mathrm{CC}_{50}$ value, no difference in cell viability was found compared with mock-treated cells. Thus, in subsequent experiments merimepodib was used at concentrations of no more than $25 \mu \mathrm{M}$.

\subsection{Antiviral effects assay}

For the antiviral effects assay, IBRS-2 cells were seeded in 96-well plates and left overnight to attach. The next day, the cells were infected with a $100 \mathrm{TCID}_{50}$ of FMDV O/MY98/BY/2010 and the $\mathrm{IC}_{50}$ of merimepodib on FMDV was determined. The result is shown in Table 1 and Fig. 2; the $\mathrm{IC}_{50}$ was evaluated to be 7.859 and $2.876 \mu \mathrm{M}$ in the cells infected with FMDV O/MY98/BY/2010 and FMDV A/GD/MM/2013, respectively. Fig. 2A and 2B indicates that FMDV infection (O/MY98/ $\mathrm{BY} / 2010$ and $\mathrm{A} / \mathrm{GD} / \mathrm{MM} / 2013)$ were inhibited significantly with treatment of merimepodib at $12 \mu \mathrm{M}$ and $3 \mu \mathrm{M}$. To confirm the reduction of virus titer induced by merimepodib, the levels of FMDV 2B mRNA and VP1 protein were detected using Q-PCR and IFA analysis, respectively (Figs. 2 and 3). The results showed that the FMDV and mRNA and protein levels were significantly reduced with merimepodib treatment and that this reduction occurred in a dose-dependent manner. These results suggested that merimepodib exerted antiviral activity against FMDV infection. As a previous study revealed the potential antiviral mechanisms of merimepodib to suppress IMPDH to deplete intracellular GTP pools (Tong et al., 2018), we sought to determine whether this mechanism was also involved in inhibition of FMDV. A series concentration of guanosine was added to infected cells, which were then

Table 1

Assessment of cytotoxicity and antiviral activity of merimepodib in IBRS-2 cells.

\begin{tabular}{llll}
\hline \multirow{4}{*}{ Virus } & \multicolumn{3}{l}{ Merimepodib $(\mu \mathrm{M})$} \\
\cline { 2 - 4 } & $\mathrm{CC}_{50}{ }^{\mathrm{a}}$ & $\mathrm{IC}_{50}{ }^{\mathrm{b}}$ & $\mathrm{SI}^{\mathrm{c}}$ \\
\hline $\mathrm{O} / \mathrm{MY} 98 / \mathrm{BY} / 2010$ & $47.74 \pm 1.52$ & $7.859 \pm 1.63$ & 6.07 \\
$\mathrm{~A} / \mathrm{GD} / \mathrm{MM} / 2013$ & $47.74 \pm 1.52$ & $2.876 \pm 0.47$ & 16.59 \\
\hline
\end{tabular}

${ }^{\text {a }}$ The $50 \%$ cytotoxic concentration $\left(\mathrm{CC}_{50}\right)$ for IBRS-2 cells; mean $\pm \mathrm{SD}$ of triplicate samples, determined by cell viability assay.

b Concentration(s) of merimepodib producing 50\% inhibition of virus-induced infection of three separate experiments, the result was expressed as the mean \pm SD of three separate experiments.

c Selectivity index (SI), determined by the ratio of $\mathrm{CC}_{50}$ to $\mathrm{IC}_{50}\left(\mathrm{CC}_{50} / \mathrm{IC}_{50}\right)$. 


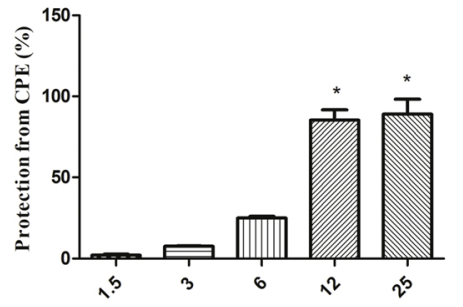

Concentration of merimepodib $(\mu M)$ against type O FMDV

C

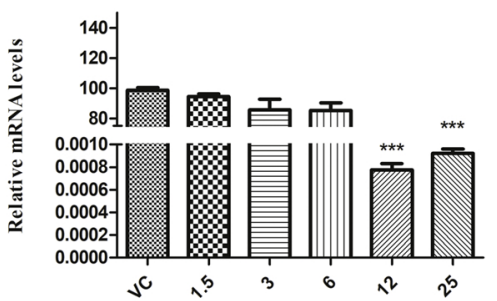

Concentration of merimepodib $(\mu \mathrm{M})$ against type $\mathrm{O}$ FMDV

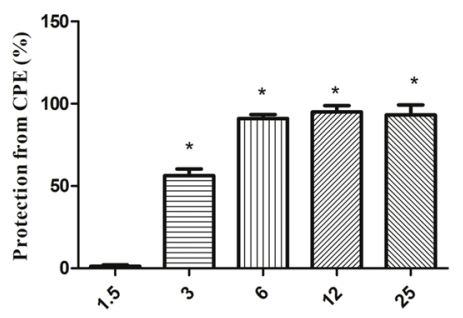

Concentration of merimepodib $(\mu \mathrm{M})$ aginst type A FMDV

D

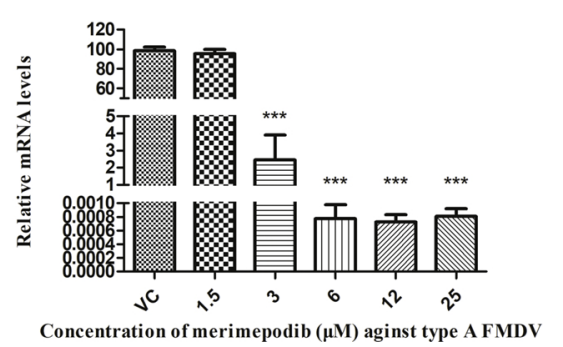

Fig. 2. Inhibition of FMDV infection by merimepodib. IBRS-2 cells in 96-well plates were infected with $100 \mathrm{TCID}_{50} \operatorname{FMDV}(\mathbf{A}, \mathbf{C})$ O/MY98/BY/2010 and (B, D) A/GD/MM/ 2013. $1 \mathrm{~h}$ later. The infection mixtures were removed and replaced with a medium containing merimepodib at specified concentrations. (A, B) The cell viability was determined after $48 \mathrm{~h}$ of post-treatment using MTS assay. (C, D) The supernatants were collected at $48 \mathrm{hpi}$, and the levels of FMDV 2B mRNA were determined using Q-PCR. GraphPad Prism software Version 5 was utilized in this study. "VC" represents those cells treated with $0.5 \%$ DMSO without merimepodib. Values. The statistical analysis was performed using SPSS version 16.0 software. The statistical significance is $* p<0.05, * * * p<0.001$. treated with merimepodib. Our results revealed that guanosine significantly attenuated the anti-FMDV effect of merimepodib (Fig. 4).

\subsection{Time-course analysis of merimepodib on FMDV replication}

In order to further investigate the time points when the antiviral replication effect of merimepodib was most prominent, we added merimepodib $(25 \mu \mathrm{M})$ to IBRS-2 cells as described in the materials and methods. Results showed that merimepodib suppress ed FMDV replication in IBRS-2 cells at $0-8 \mathrm{~h}$ p.i., while no effectively inhibitory effects were observed at $16 \mathrm{~h}$ p.i., suggesting that the effect of merimepodib on FMDV occurs primarily during the early stages of virus replication (Fig. 5).

\subsection{Merimepodib caused a significantly prolonged survival in suckling mice}

To further evaluate the antiviral efficacy of merimepodib in vivo, 3day-old suckling mice were inoculated with $30 \mu \mathrm{g}$ of merimepodib and challenged with FMDV O/MYA98/BY/2010. The non-treated and virusinfected mice began die at 36 p.i. (Fig. $6 \mathrm{~A}$ ) and at $60 \mathrm{~h}$ p.i., all the mice had died. In contrast, in the merimepodib-treated group death began to occur at $48 \mathrm{~h}$ p.i.. All the suckling mouse treated with merimepodib
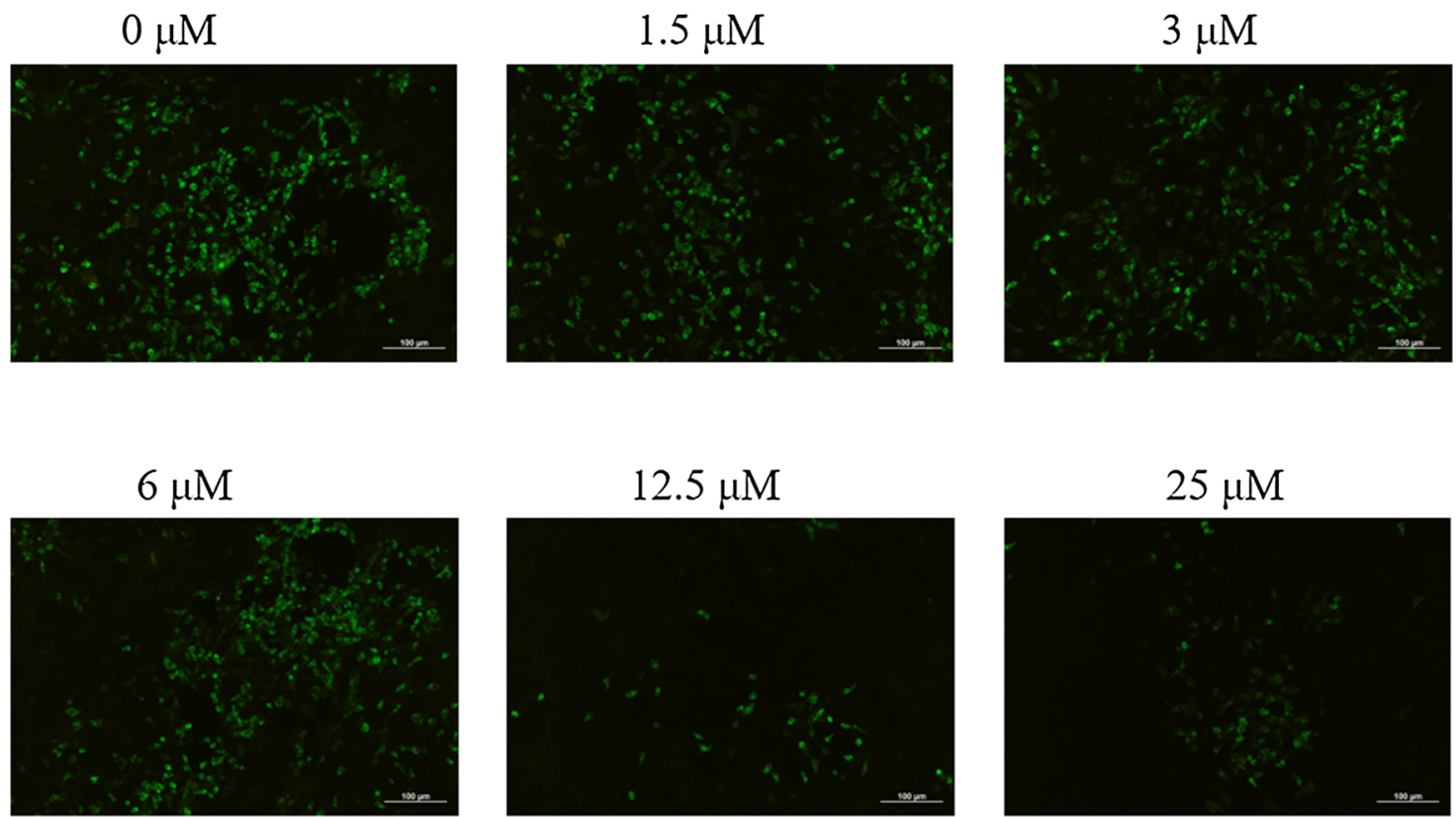

Fig. 3. Confirmation of merimepodib antiviral effect against FMDV by IFA. IBRS-2 cells in 12-well plates were infected with 100 TCID 50 FMDV O/MY98/BY/ 2010. The cells were treated with or without merimepodib at indicated concentration for $12 \mathrm{~h}$. The FMDV antigens were determined by IFA, the green fluorescence represents the intracelluar distribution of FMDV. (For interpretation of the references to colour in this figure legend, the reader is referred to the web version of this article). 
A

B

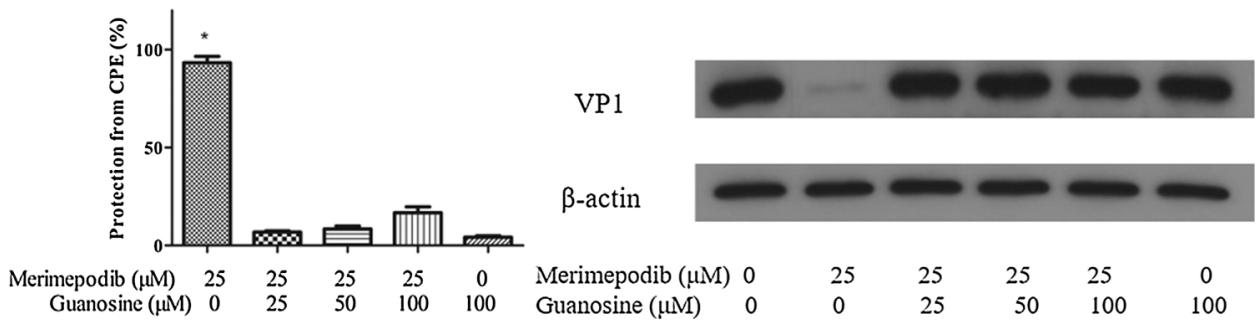

Fig. 4. The attenuated effect by guanosine supplementation. A. Effect of guanosine supplementation on viral cytopathic effect of FMDV. B. The viral VP1 protein and $\beta$-actin were detected by western blot. $\beta$-actin was used as an internal control. A serial dilution of guanosine (from $100 \mu \mathrm{M}$ to $25 \mu \mathrm{M}$ ) were added to FMDV infected IBRS-2 cells, when treated with $25 \mu \mathrm{M}$ merimepodib for $48 \mathrm{~h}$. Cell viability and VP1 protein was analysed as described above. Data are presented as mean \pm S.D. of three independent experiments. The statistical significance is $* p<0.05$. died within $108 \mathrm{~h}$ p.i.. The survival rate of merimepodib-infected mice was significantly higher than that of non-treated infected mice at 100 $\mathrm{LD}_{50}$ FMDV O/MYA98/BY/2010 ( $\left.\mathrm{P}<0.0001\right)$. Consistent with this result, following an inoculation with a dose of $100 \times \mathrm{LD}_{50} \mathrm{FMDV}$, the merimepodib-treated group was visually healthy and the onset of FMD symptoms were delayed (Fig. 6B). The results indicated that treatment with merimepodib resulted in obviously prolonged survival time of suckling mice. The heart tissue of suckling mice was sampled $34 \mathrm{~h}$ after challenge and histologically examined by H\&E staining (Fig.7A and B). Results indicated that myocardial interstitial hemorrhage, inflammatory cell infiltration, and myocardial fibrosis were all evident in untreated virus-infected suckling mice, while only a small amount of inflammatory cell infiltration and myocardial fibronectin degeneration was observed after treatment with merimepodib. No significant reduction in the amount of the FMDV antigen was observed in mice treated with merimepodib (Fig. 7C and D).

\section{Discussion}

FMD, a transmissible disease, may spread rapidly over vast areas and cause devastating effects on the livestock industry. Many approaches have been proposed by researchers to control FMD (Bekerman and Einav, 2015), including a series of broad-spectrum antivirals targeting host factors or direct antiviral agents capable of inhibiting multiple viruses. IMPDH is an enzyme involved in the de novo synthesis of guanine nucleotides (Hedstrom, 2009). Therefore, inhibitors of IMPDH may represent a novel therapeutic regimens to control viral outbreaks; for instance, ribavirin and mycophenolic acid have shown activities against Chikungunya (Khan et al., 2011), Junin (Westover et al., 2016), Lassa, and Ebola viruses (Olschlager et al., 2011). Very recently, it has been demonstrated that merimepodib inhibits several viral pathogens. However, its effect against FMDV had not yet been explored. This study initially assessed the anti-FMDV activity of merimepodib in vitro and in vivo.

Our results revealed that merimepodib significantly inhibited FMDV replication in IBRS-2 cells; specifically at concentrations of $12 \mu \mathrm{M}$ and $25 \mu \mathrm{M}$. However, other concentrations could provide effective protection to IBRS-2 cells from CPE. Of note, at concentrations greater than
$50 \mu \mathrm{M}$, merimepodib induced cytotoxic effects in cells. Therefore, in order to minimize the risk of merimepodib toxicity, careful monitoring and adjustment of merimepodib dosage in animals will be needed in the future. Importantly, when IBRS-2 cells were exposed to merimepodib at several points in the viral replication stage, we found that that merimepodib decreased viral replication when treated within $8 \mathrm{~h}$ p.i., suggesting that the early time of viral replication is the target for the antiviral effect of merimepodib. In addition, the potent anti-FMDV effect of merimepodib was also alleviated by guanosine supplementation. Therefore, purine nucleotide depletion by merimepodib is an important mechanism in inhibiting FMDV. Previously, researchers studying FMD demonstrated that interferons have activity against a wide variety of viruses irrespective of the serotype or strain. Consist with their finding as well as the study from Tong and others (Tong et al., 2018) we found that merimepodib was also able to provide effective protection to cells against two different serotypes of FMDV. Overall these results supported that merimepodib had broad-spectrum antiviral activity against RNA virus.

Although merimepodib has been demonstrated to inhibit several viral pathogens, its antiviral efficacy in vivo remains little reported. In this study, the in vivo biological activity of merimepodib was evaluated in suckling mice. We found suckling mouse treated with $30 \mu \mathrm{g}$ merimepodib could significantly prolong the survival time of suckling mouse, approximately $48 \mathrm{~h}$, compared with non-treated suckling mouse. In the future, in vivo experiments in cattle and pigs are will be needed to determine the true potential of merimepodib as an adjunct control measure for FMD outbreaks.

In recent years, combination antiviral therapy has become common practice in several viral infections disease including combination therapy of ribavirin and interferon, which has historically been the standard therapy against virus outbreaks (Feld and Hoofnagle, 2005). In terms of FMD, researchers have demonstrated that the combination of interferon and siRNA or interferon and ribavirin had synergistic antiviral effects both in vitro and in vivo (Kim et al., 2012). Recently, combination therapy using merimepodib and ribavirin or T-705 showed increased efficacy in suppression of viral replication in virus production assays (Tong et al., 2018). Therefore, it would of interest to explore whether merimepodib has a synergistic or additive effect both in vitro
A

$\mathrm{B}$

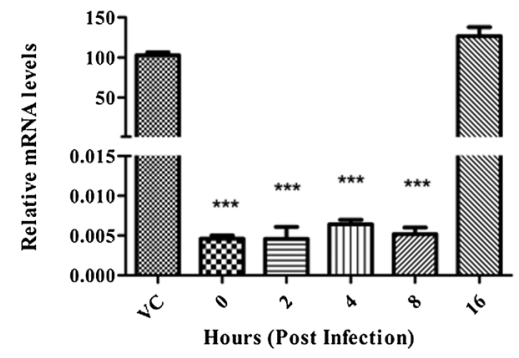

VP1

$\beta$-actin

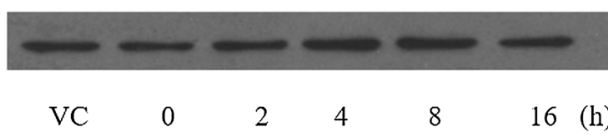

Fig. 5. Merimepodib exhibits antiviral activity against FMDV infection at the early stage of replication. IBRS-2 cells in 12-well plates were infected with 100 TCID $_{50}$ FMDV O/ MY98/BY/2010. Merimepodib at $25 \mu \mathrm{M}$ was added at specified time points that represent the time points of during adsorption $(0 \mathrm{~h})$, and $0,2,4,8$ and $16 \mathrm{~h}$ p.i. Level of FMDV 2B mRNA (A) and VP1 protein were detected (B). Data are presented as mean \pm S.D. of three independent experiments. "VC" represents those cells treated with $0.5 \%$ DMSO without merimepodib. The statistical significance is $* * * p<0.001$. 
A

B

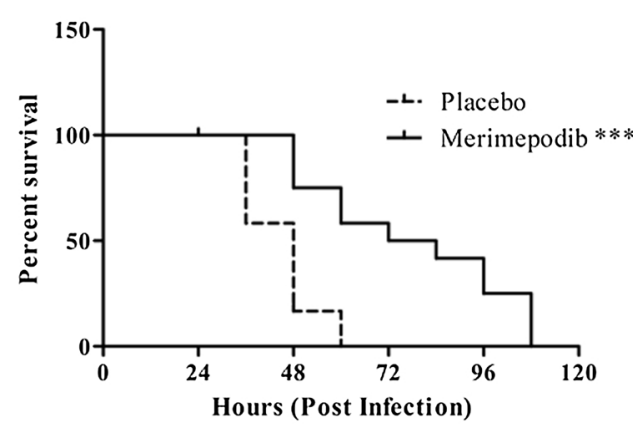

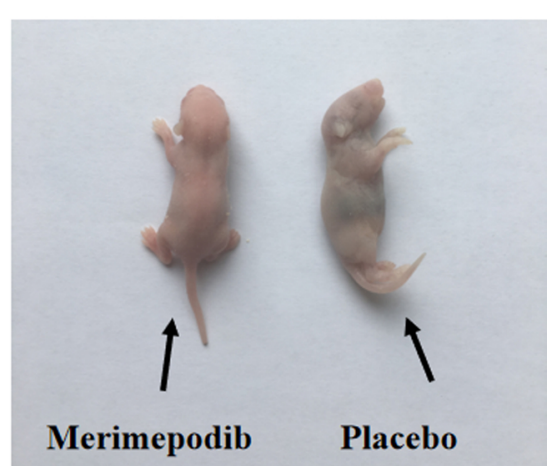

Fig. 6. in vivo activity of merimepodib. Suckling mice were inoculated intranasally with $30 \mu \mathrm{g}$ Merimepodib or PBS containing $10 \%$ DMSO and 5\% Tween- 80 (Control). $2 \mathrm{~h}$ later, all the animals was infected with 100 $\mathrm{LD}_{50}$ FMDV O/MY98/BY/2010. Animal survival was monitored for 5 days. (A) The survival curve was performed using GraphPad Prism5. (B) The morphological observation of treated and non-treated infected mice at 60 hpi.
A

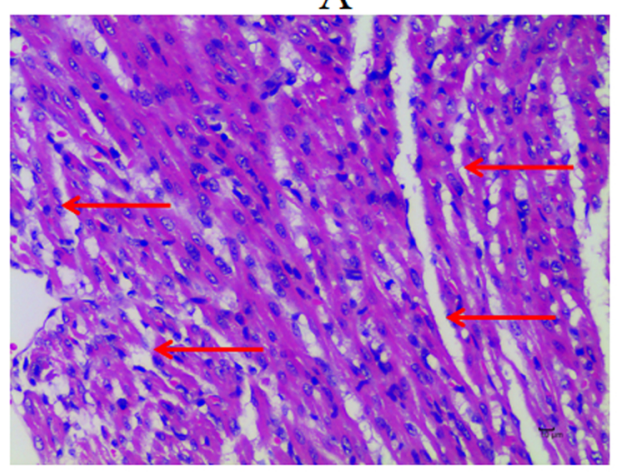

C

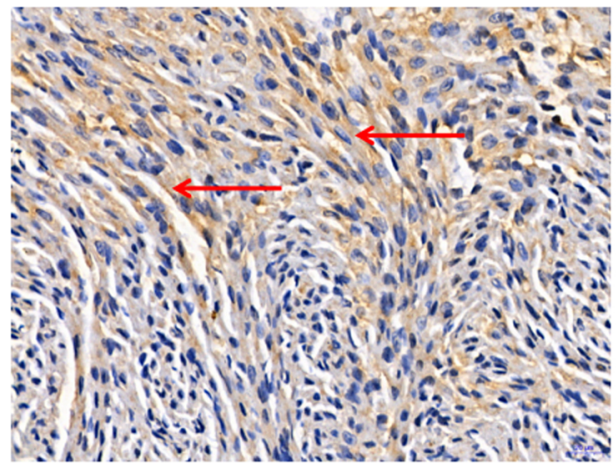

$\mathrm{B}$

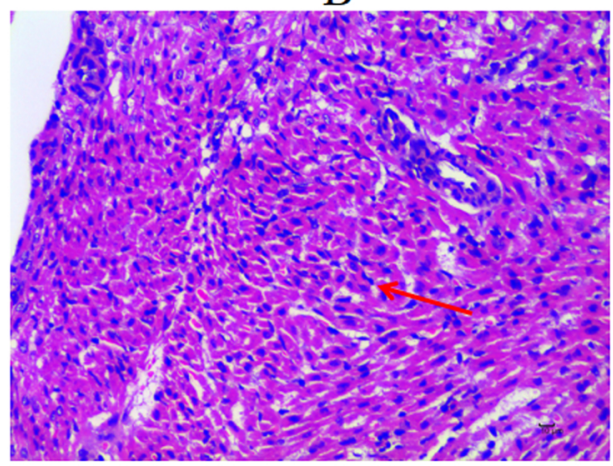

$\mathrm{D}$

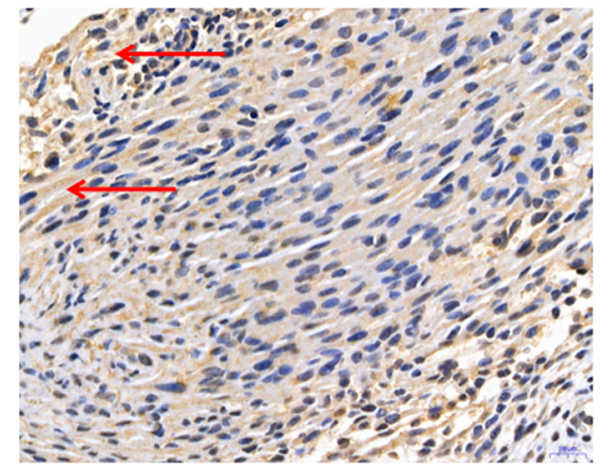

Fig. 7. Histological and immunohistochemical expression of FMDV analysis of heart tissues in FMDV-infected mice. (A, B) Mice were sacrificed at $34 \mathrm{~h}$-postchallenge. Heart tissues were then collected and fixed in $4 \%$ formaldehyde, paraffin embedded, sectioned, and stained with H\&E. Representative images from each group are shown $(N=5)$. Tissue damage was identified and is indicated by red arrows (magnification, $400 \times$ ). (C, D) The immunohistochemical expression of FMDV protein for heart tissue was detected using hyper-immune serum raised against type $\mathrm{O}$ FMDV. Representative images from each group are shown $(\mathrm{N}=5)$. FMDV antigen was identified and is indicated by red arrows (magnification, $400 \times$ ). (A, C) Heart tissue from non-treated infected mice. (B, D) Heart tissue from treated and infected mice. (For interpretation of the references to colour in this figure legend, the reader is referred to the web version of this article). and in vivo on the treatment of FMDV infections when combined with ribavirin, T-705 or interferons.

Taken together, we have shown that merimepodib showed antiviral effects against FMDV in vitro and in vivo. In addition, the inhibition of FMDV replication mainly occurs at the early stage of de novo infection. Further studies are necessary for a better understanding of the exact mechanism of action of merimepodib. The antiviral effects of merimepodib may provide a basis to further develop a potent antiviral agent in combination with other antiviral molecules or anti-FMDV vaccines against FMD.

\section{Declaration of Competing Interest}

None declared

\section{Acknowledgments}

This work was supported by grants from the National Key Research and Development Program of China (2017YFD0500902 and 2016YFE0204100) and the Key R\&D Program of Gansu Province of China (Grant No. 17YF1NA070).

\section{References}

Bachrach, H.L., 1968. Foot-and-mouth disease. Annu. Rev. Microbiol. 22, 201-244. Bekerman, E., Einav, S., 2015. Infectious disease. Combating emerging viral threats. Science. 348, 282-283.

Belsham, G.J., Jamal, S.M., Tjornehoj, K., Botner, A., 2011. Rescue of foot-and-mouth disease viruses that are pathogenic for cattle from preserved viral RNA samples. PLoS One 6, e14621.

Diaz-San, S.F., Weiss, M., Perez-Martin, E., Koster, M.J., Zhu, J., Grubman, M.J., de Los, S.T., 2011. Antiviral activity of bovine type III interferon against foot-and-mouth disease virus. Virology. 413, 283-292.

Domingo, E., Escarmis, C., Baranowski, E., Ruiz-Jarabo, C.M., Carrillo, E., Nunez, J.I., Sobrino, F., 2003. Evolution of foot-and-mouth disease virus. Virus Res. 91, 47-63.

Feld, J.J., Hoofnagle, J.H., 2005. Mechanism of action of interferon and ribavirin in treatment of hepatitis C. Nature. 436, 967-972.

Golde, W.T., Pacheco, J.M., Duque, H., Doel, T., Penfold, B., Ferman, G.S., Gregg, D.R., Rodriguez, L.L., 2005. Vaccination against foot-and-mouth disease virus confers complete clinical protection in 7 days and partial protection in 4 days: use in 
emergency outbreak response. Vaccine 23, 5775-5782.

Hedstrom, L., 2009. IMP dehydrogenase: structure, mechanism, and inhibition. Chem. Rev. 109, 2903-2928.

Khan, M., Dhanwani, R., Patro, I.K., Rao, P.V., Parida, M.M., 2011. Cellular IMPDH enzyme activity is a potential target for the inhibition of Chikungunya virus replication and virus induced apoptosis in cultured mammalian cells. Antiviral Res. 89, 1-8.

Kim, S.M., Park, J.H., Lee, K.N., Kim, S.K., Ko, Y.J., Lee, H.S., Cho, I.S., 2012. Enhanced inhibition of foot-and-mouth disease virus by combinations of porcine interferonalpha and antiviral agents. Antiviral Res. 96, 213-220.

Knowles, N.J., Samuel, A.R., 2003. Molecular epidemiology of foot-and-mouth disease virus. Virus Res. 91, 65-80.

Li, S.F., Gong, M.J., Sun, Y.F., Shao, J.J., Zhang, Y.G., Chang, H.Y., 2019. In vitro and in vivo antiviral activity of mizoribine against foot-and-Mouth disease virus. Molecules. 24, 1723.

Marcellin, P., Horsmans, Y., Nevens, F., Grange, J.D., Bronowicki, J.P., Vetter, D., Purdy, S., Garg, V., Bengtsson, L., McNair, L., Alam, J., 2007. Phase 2 study of the combination of merimepodib with peginterferon-alpha2 $\mathrm{b}$, and ribavirin in nonresponders to previous therapy for chronic hepatitis C. J. Hepatol. 47, 476-483.

Markland, W., McQuaid, T.J., Jain, J., Kwong, A.D., 2000. Broad-spectrum antiviral ac tivity of the IMP dehydrogenase inhibitor VX-497: a comparison with ribavirin and demonstration of antiviral additivity with alpha interferon. Antimicrob. Agents Chemother. 44, 859-866.
Moraes, M.P., de Los, S.T., Koster, M., Turecek, T., Wang, H., Andreyev, V.G., Grubman, M.J., 2007. Enhanced antiviral activity against foot-and-mouth disease virus by a combination of type I and II porcine interferons. J. Virol. 81, 7124-7135.

Olschlager, S., Neyts, J., Gunther, S., 2011. Depletion of GTP pool is not the predominant mechanism by which ribavirin exerts its antiviral effect on Lassa virus. Antiviral Res. 91, 89-93.

Rustgi, V.K., Lee, W.M., Lawitz, E., Gordon, S.C., Afdhal, N., Poordad, F., Bonkovsky, H.L., Bengtsson, L., Chandorkar, G., Harding, M., McNair, L., Aalyson, M., Alam, J., Kauffman, R., Gharakhanian, S., McHutchison, J.G., 2009. Merimepodib, pegylated interferon, and ribavirin in genotype 1 chronic hepatitis $\mathrm{C}$ pegylated interferon and ribavirin nonresponders. Hepatology 50, 1719-1726.

Tong, X., Smith, J., Bukreyeva, N., Koma, T., Manning, J.T., Kalkeri, R., Kwong, A.D. Paessler, S., 2018. Merimepodib, an IMPDH inhibitor, suppresses replication of Zika virus and other emerging viral pathogens. Antiviral Res. 149, 34-40.

Usharani, J., Park, S.Y., Cho, E.J., Kim, C., Ko, Y.J., Tark, D., Kim, S.M., Park, J.H., Lee, K.N., Lee, M.H., Lee, H.S., 2017. Antiviral activity of ovine interferon tau 4 against foot-and-mouth disease virus. Antiviral Res. 143, 134-141.

Westover, J.B., Sefing, E.J., Bailey, K.W., Van Wettere, A.J., Jung, K.H., Dagley, A., Wandersee, L., Downs, B., Smee, D.F., Furuta, Y., Bray, M., Gowen, B.B., 2016. Lowdose ribavirin potentiates the antiviral activity of favipiravir against hemorrhagic fever viruses. Antiviral Res. 126, 62-68. 